F. Reprod. Fert. (1969) 18, 287-295

\title{
RADIOSENSITIVITY OF OOCYTES IN POST-NATAL GUINEA-PIGS
}

\author{
J. M. IOANNOU \\ Department of Anatomy, University of Birmingham
}

(Received 14th March 1968)

\begin{abstract}
Summary. The guinea-pig differs from other rodents in that the ovary of the post-natal animal contains two distinct populations of oocyte at diplotene. A 'large' oocyte, comparable to that of other mammals, is found in some primordial follicles; in others a second, 'contracted', type occurs. As the animal ages the contracted cell predominates. The radiosensitivity of these two cell-types has been investigated.

Ninety-eight animals received unilateral ovarian $\mathrm{X}$-irradiation ( 300 to $15,000 \mathrm{r}$ ). The numbers of germ cells in the irradiated ovary were counted from 3 to 32 days later, and compared with those found in the untreated, contralateral ovary of each animal.

Irradiation killed large oocytes, and induced contracted cells either to degenerate or undergo transformation to the large nuclear type. Gontracted oocytes were consistently and significantly more sensitive to irradiation, even over a short (3 days) post-irradiation interval. Over a longer interval (16 or 32 days) a dose-dependent response was revealed: the higher the dose, the smaller the number of surviving oocytes. Although the $\mathbf{L D}_{\mathbf{5 0} 32}$ for oocytes in primordial follicles was as low as $500 \mathrm{r}$, $15,000 \mathrm{r}$ was required to eliminate all the oocytes.
\end{abstract}

\section{INTRODUGTION}

The sensitivity of mammalian germ cells to radiation-induced cell death depends on their stage of development at irradiation. Thus, in the female rat, the early stages of meiotic prophase are more sensitive than the later ones, and oocytes become progressively more resistant as they pass from the leptotene through to the early diplotene stage (Beaumont, 1961, 1962). As the oocyte passes into the dictyate phase, however, and becomes enveloped in a primary follicle, sensitivity increases. For instance, the mean population of oocytes in normal rats aged 25 days post partum (p.p.) is 6160 ; following exposure to $50 \mathrm{r}$ at the pachytene stage (Day 0 ) it only fell to 5870 , whereas the same dose given at the age of 5 days (onset of the dictyate stage) resulted in a drop to 1130 by 25 days p.p. (Beaumont, 1961, 1962). Slightly larger oocytes surrounded by a single layer of cuboidal granulosa cells were relatively less sensitive, $26 \%$ surviving for 4 days after exposure to $4400 \mathrm{r}$ (Mandl, 1959). Similar results have been described for the mouse by Peters (1961) and Oakberg \& Clark (1961). 
These observations contrast sharply with those made on the monkey and the guinea-pig. In the monkey, Van Eck-Vermande (1956) reported that many primordial follicles survived exposure to $1200 \mathrm{r}$ for at least 7 days. Baker (1966) confirmed and extended this conclusion, and stated that the $\mathrm{LD}_{50 / 30}$ for germ cells at this developmental stage is about $5000 \mathrm{r}$.

Oakberg \& Clark (1964) reported that a dose of $200 \mathrm{r}$ was necessary to eliminate $50 \%$ of the primordial oocytes and nearly all of the growing follicles in the guinea-pig within 2 to 3 days. In this respect the guinea-pig would appear to be more similar to the monkey than to the rat and mouse, despite its closer taxonomic relationship to the latter. These observations indicate that some basic difference may exist between the relative sensitivity of primordial and growing follicles in the monkey on the one hand, and the rat and mouse on the other, with the guinea-pig lying intermediate between these groups. The suggestion has been made that these differences are related to the dissimilarity of chromosomal configuration in the germ cells at corresponding stages of follicular development (see Mandl, 1964). Thus, oocytes in primordial follicles in the rat and mouse exhibit a typical dictyate configuration, seemingly absent from monkey ovaries (Baker, 1963) and from the guinea-pig (Ioannou, 1964). Moreover, the ovary of the post-natal guinea-pig shows an additional feature in oocyte development-the contraction of oocytes at diplotene (Ioannou, 1964). Contracted oocytes are not encountered in any great numbers until about 1 month p.p., roughly the time of puberty. During the following month, however, more and more of the large primordial oocytes appear in the contracted configuration, until at 2 months some $88 \%$ of the germ cell population is of this type. These cells are limited to the primordial follicles, whereas the healthy growing and Graafian follicles all have oocytes with the larger nucleus. The contracted condition follows the appearance of a typical diplotene configuration, and possibly precedes a return to the 'lampbrush' chromosomal type (still at the diplotene stage of meiotic prophase) in growing follicles (see Ioannou, 1964).

In view of the apparent conflict between the reports on the guinea-pig and those on other rodents, it seemed of particular interest to repeat the observations of Oakberg \& Clark (1964), and to extend them over a range of ages where the ratio between large and contracted oocytes was known to change.

\section{MATERIALS AND METHODS}

Ninety-eight female guinea-pigs were used in three experiments.

\section{Procedures for surgery and irradiation}

The animals were weighed and then anaesthetized by an intraperitoneal injection of either pentobarbitone sodium (Nembutal) at a dose rate of 0.72 $\mathrm{ml} / \mathrm{kg}$ body weight, or tribromoethanol solution (Avertin) at $9.0 \mathrm{ml} / \mathrm{kg}$ body weight.

In Exps. I and II, one ovary was removed surgically and served as a control; the contralateral ovary was then exposed through a dorso-lumbar incision. A superficial X-irradiation apparatus was used, fitted with an applicator $2 \mathrm{~cm}$ in diameter and operated at $100 \mathrm{kV}$ and $5 \mathrm{~mA}$, to give a dose rate of $420 \mathrm{r} / \mathrm{min}$ 
with no filtration. All adjacent tissues were shielded with lead plates during irradiation. In Exp. III, the non-irradiated ovary was left in situ and removed at the end of the post-irradiation interval together with its exposed partner.

Exp. I. Twenty-two animals, whose ages ranged from 1 to 30 months (see Table 1), were exposed to $300 \mathrm{r}$ and killed after 3 days.

Exp. II. Twenty-six adult animals were killed 3 days after irradiation with $600,1000,1500,5000$ or $10,000 \mathrm{r}$, each group consisting of five or six specimens (see Table 2).

Exp. III. Fifty adult animals were killed 16 or 32 days after exposure to 500 , $1000,5000,10,000$ or $15,000 \mathrm{r}$ (see Table 3 ).

\section{Histological procedures}

Ovaries were dissected free from all surrounding tissues before fixation for up to $24 \mathrm{hr}$ in Bouin's aqueous fluid. After fixation the material was transferred to $70 \%$ alcohol, dehydrated, and then embedded in paraffin wax. Serial sections were cut at 5 or $7 \mu$, and stained with Weigert's iron haematoxylin and chromotrop 2R.

\section{Quantitative histological studies}

The numbers of oocytes were assessed by counts of all germ cells made on every tenth serial section of the ovary, using the nucleolus as a marker-large oocytes only (see Mandl \& Zuckerman, 1951; Green \& Zuckerman, 1951, 1954). Since contracted oocytes lack a prominent nucleolus (Ioannou, 1964), only those cells were counted which were judged to be cut through or near the centre. The germ cells were then grouped into three classes by their degree of follicular development, as follows:

Stage I: more or less complete follicular envelope of flattened epithelial cells.

Stage II: complete covering of one layer of cuboidal cells.

Stage III : two layers of granulosa cells.

Oocytes in larger follicles were disregarded because (a) their numbers were invariably small relative to the total population of oocytes; (b) cyclical fluctuations in their numbers would confuse the results; (c) the destruction of ovarian secretory tissues after irradiation might indirectly affect the numbers of growing follicles.

Germ cells were further classified as large or contracted (nuclear configuration; see above), and normal or atretic. The total population of oocytes was then obtained by multiplying by ten.

\section{Qualitative observations}

\section{RESULTS}

Microscopic examination of the ovaries revealed radiation-induced changes. Atresia of contracted germ cells took a number of forms. Sometimes the nucleus became pyknotic, the chromosomes losing their separate identity and coalescing into a single, irregularly shaped chromatin mass (Pl. 1, Fig. 2; cf. Fig. 1, 
showing a normal contracted oocyte). The nuclear membrane of such cells was no longer visible with the light microscope, and nuclear fragments were occasionally observed within the cell cytoplasm.

There appeared to be more cells showing partial contraction after irradiation. Indeed, some atretic cells had thickly condensed chromosomes spread through the nuclear volume and not gathered into the more typical ball of chromatin. Occasionally, in oocytes enclosed by a large follicle, the chromosomes had fragmented, so that tiny blobs of chromatin were visible instead of chromatin threads (Pl. 1, Fig. 3). Such cells sometimes contained a pseudomaturation spindle, although the cytoplasm and the follicular granulosa cells might both appear healthy.

\section{TABLE 1}

NUMBERS OF GERM GELLS FOUND IN OVARIES OF GUINEA-PIGS KILLED 3 DAYS AFTER X-IRRADIATION WITH 300 R

\begin{tabular}{|c|c|c|c|c|c|c|c|}
\hline \multirow{3}{*}{$\begin{array}{c}\begin{array}{c}\text { No. of } \\
\text { animals }\end{array} \\
4\end{array}$} & \multirow{3}{*}{$\frac{\begin{array}{c}\text { Age } \\
\text { (months) }\end{array}}{1}$} & \multirow[b]{3}{*}{$\begin{array}{l}\text { Irrad. } \\
\text { Control }\end{array}$} & \multicolumn{4}{|c|}{ Mean numbers and percentages of germ cells } & \multirow{3}{*}{$\frac{\begin{array}{c}\text { Irrad./Control } \\
(\%)\end{array}}{79}$} \\
\hline & & & \multicolumn{2}{|c|}{ Large } & \multirow{2}{*}{$\begin{array}{c}\text { Contracted } \\
3071 \\
7785\end{array}$} & \multirow{2}{*}{$\begin{array}{l}\text { Total } \\
10349 \\
13187\end{array}$} & \\
\hline & & & $\begin{array}{l}7278 \\
5402\end{array}$ & $\begin{array}{l}70 \% \\
41 \%\end{array}$ & & & \\
\hline 2 & $1 \frac{1}{2}$ & $\begin{array}{l}\text { Irrad. } \\
\text { Control }\end{array}$ & $\begin{array}{r}8623 \\
930\end{array}$ & $66 \%$ & $\begin{array}{l}4480 \\
9500\end{array}$ & $\begin{array}{l}13103 \\
10429\end{array}$ & 126 \\
\hline 5 & 2 & $\begin{array}{l}\text { Irrad. } \\
\text { Control }\end{array}$ & $\begin{array}{r}2165 \\
895\end{array}$ & $17 \%$ & $\begin{array}{r}10588 \\
9144\end{array}$ & $\begin{array}{l}12753 \\
10039\end{array}$ & 127 \\
\hline 5 & 3 & $\begin{array}{l}\text { Irrad. } \\
\text { Control }\end{array}$ & $\begin{array}{l}673 \\
902\end{array}$ & $\begin{array}{l}6 \% \\
9 \%\end{array}$ & $\begin{array}{r}10628 \\
9062\end{array}$ & $\begin{array}{r}11301 \\
9964\end{array}$ & 113 \\
\hline 3 & 12 & $\begin{array}{l}\text { Irrad. } \\
\text { Control }\end{array}$ & $\begin{array}{l}832 \\
424\end{array}$ & $12 \%$ & $\begin{array}{l}5933 \\
6643\end{array}$ & $\begin{array}{l}6765 \\
7067\end{array}$ & 96 \\
\hline 1 & 18 & $\begin{array}{l}\text { Irrad. } \\
\text { Control }\end{array}$ & $\begin{array}{l}300 \\
485\end{array}$ & $\begin{array}{l}6 \% \\
5 \%\end{array}$ & $\begin{array}{l}5060 \\
8810\end{array}$ & $\begin{array}{l}5360 \\
9295\end{array}$ & 58 \\
\hline 2 & 30 & $\begin{array}{l}\text { Irrad. } \\
\text { Control }\end{array}$ & $\begin{array}{l}953 \\
912\end{array}$ & $10 \%$ & $\begin{array}{r}9035 \\
11415\end{array}$ & $\begin{array}{r}9988 \\
12327\end{array}$ & 81 \\
\hline
\end{tabular}

The granulosa cells of some vesicular follicles showed signs of dispersal without pyknosis, although the oocyte they enclosed sometimes appeared normal. In other Graafian follicles, however, the oocytes showed nuclear contraction (Pl. 1, Fig. 4).

Very occasionally, binucleate oocytes (P1. 1, Fig. 5) and binovular follicles were observed. These often appeared normal, but sometimes showed pseudomaturation spindles or other signs of atresia.

\section{Quantitative studies}

Exp. I. The effects of exposing animals aged 1 to 30 months to $300 \mathrm{r}$ of X-rays are shown in Table 1 . There was a highly significant $(P<0.001)$ fall in the numbers of contracted oocytes in treated ovaries, particularly in animals aged less than 2 months. In marked contrast, there was no consistent change in the total population of germ cells.

Exp. II. Adult animals were exposed to 600 to $10,000 \mathrm{r}$ and killed after 3 days, 
PLA'L' 1
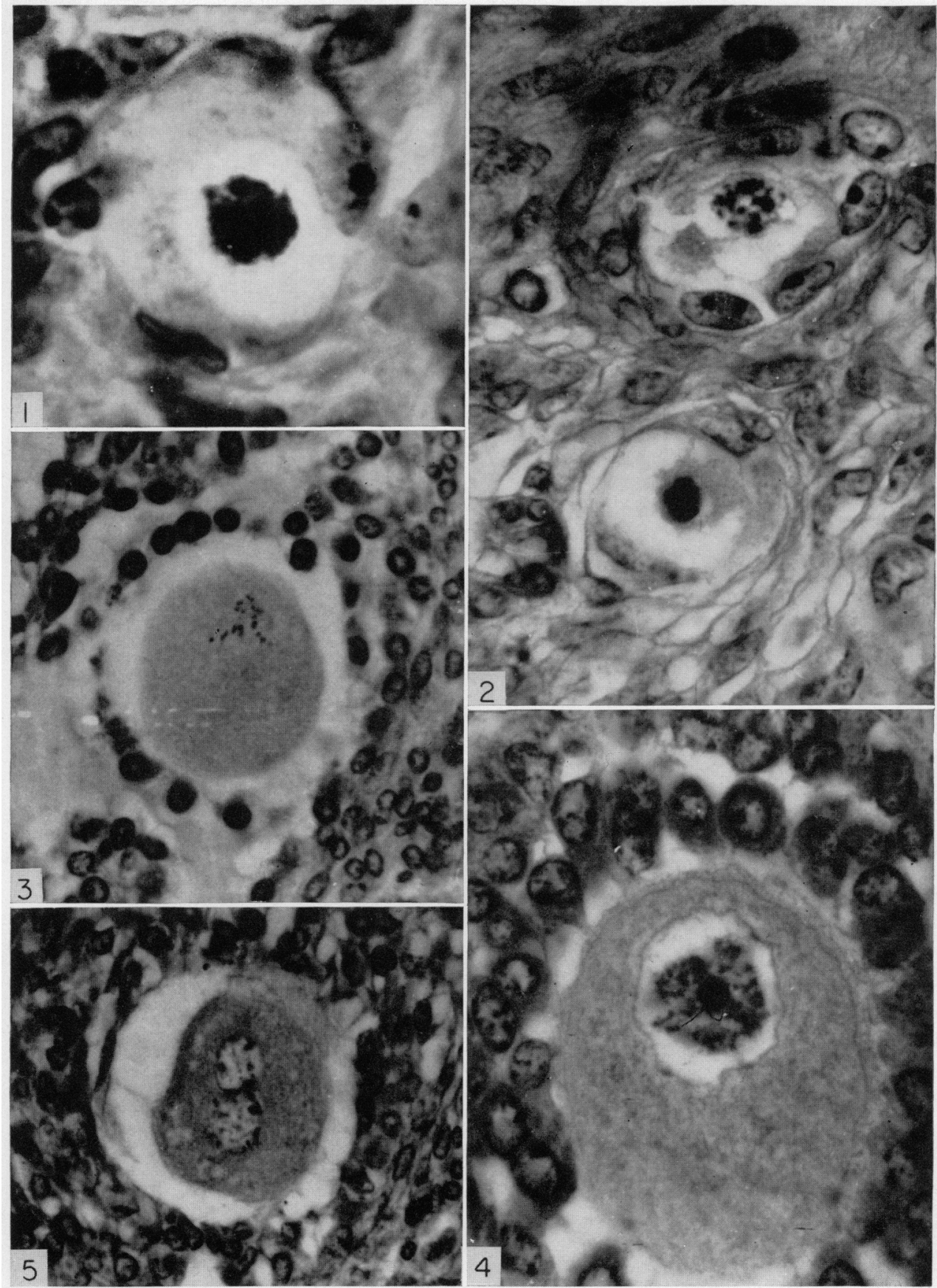

Fis. 1 . Formal contracted oocete. $\times 1205$.

lis. 2. Larly stage of pyknosis in a contracted oocyte above: later stage below: $\times 1205$.

Fif: 3. 1)egenerating oocyte in a Gratan follicle. $\times 500$.

lis. 4. Contracted nucleus in a small Grafian follicle. $\times 1205$.

fire, j. Binucleate oocye in a large follicle. $\times 500$.

(Facing fr. 290 ) 
the results of the quantitative analysis being shown in Table 2. The fall in the total numbers of germ cells after irradiation, although consistent, was not statistically significant. On the other hand, there was a highly significant fall in the numbers of contracted oocytes $(P<0.001)$, coupled with an equally significant increase in the numbers of large primordial oocytes $(P<0.001)$ in treated ovaries.

The findings from these two experiments lead to two conclusions: firstly, that the nuclear configuration of contracted oocytes changes to the large condition as a result of irradiation; secondly, that oocytes in the guinea-pig are otherwise highly resistant to short-term radiation-induced damage.

Exp. III. In the third experiment, adult females were exposed to 500 to $15,000 \mathrm{r}$ and killed after either 16 or 32 days. The results are shown in Table 3

\section{TABLE 2}

NUMBERS OF GERM CELLS FOUND IN OVARIES OF GUINEA-PIGS KILLED 3 DAYS AFTER X-IRRADIATION WTrH 600 TO $10,000 \mathrm{R}$

\begin{tabular}{|c|c|c|c|c|c|c|c|}
\hline \multirow{3}{*}{$\begin{array}{c}\begin{array}{c}\text { No. of } \\
\text { animals }\end{array} \\
5\end{array}$} & \multirow{3}{*}{$\begin{array}{c}\begin{array}{c}\text { Dose } \\
(r)\end{array} \\
600\end{array}$} & \multirow[b]{3}{*}{$\begin{array}{l}\text { Irrad. } \\
\text { Control }\end{array}$} & \multicolumn{4}{|c|}{ Mean numbers and percentages of germ cells } & \multirow{3}{*}{$\begin{array}{c}\begin{array}{c}\text { Irrad./Control } \\
(\%)\end{array} \\
85\end{array}$} \\
\hline & & & \multicolumn{2}{|c|}{ Large } & \multirow{2}{*}{$\begin{array}{c}\text { Contracted } \\
5542 \\
7814\end{array}$} & \multirow{2}{*}{$\begin{array}{r}\text { Total } \\
7536 \\
8898\end{array}$} & \\
\hline & & & $\begin{array}{l}1994 \\
1084\end{array}$ & $27 \%$ & & & \\
\hline 5 & 1000 & $\begin{array}{l}\text { Irrad. } \\
\text { Control }\end{array}$ & $\begin{array}{l}1584 \\
1228\end{array}$ & $\begin{array}{l}29 \% \\
12 \%\end{array}$ & $\begin{array}{l}7378 \\
8178\end{array}$ & $\begin{array}{l}8962 \\
9406\end{array}$ & 95 \\
\hline 5 & 1500 & $\begin{array}{l}\text { Irrad. } \\
\text { Control }\end{array}$ & $\begin{array}{l}2270 \\
1876\end{array}$ & $\begin{array}{l}36 \% \\
21 \%\end{array}$ & $\begin{array}{l}4248 \\
6082\end{array}$ & $\begin{array}{l}6518 \\
7958\end{array}$ & 82 \\
\hline 6 & 5000 & $\begin{array}{l}\text { Irrad. } \\
\text { Control }\end{array}$ & $\begin{array}{l}2797 \\
1033\end{array}$ & $\begin{array}{l}32 \% \\
11 \%\end{array}$ & $\begin{array}{r}6727 \\
10622\end{array}$ & $\begin{array}{r}9523 \\
11655\end{array}$ & 82 \\
\hline 5 & 10000 & $\begin{array}{l}\text { Irrad. } \\
\text { Control }\end{array}$ & $\begin{array}{r}1024 \\
626\end{array}$ & $19 \%$ & $\begin{array}{r}7432 \\
10364\end{array}$ & $\begin{array}{r}8366 \\
10990\end{array}$ & 76 \\
\hline
\end{tabular}

and Text-fig. 1. A clear dose-dependent effect was revealed: the higher the dose of radiation, the smaller the percentage of surviving germ cells. In addition, for any given dose of $\mathrm{X}$-rays, fewer germ cells survived the 32-day interval than were present after 16 days.

As in the two previous experiments, the absolute number of cells with contracted nuclei was consistently and significantly reduced after exposure to each of these doses, indicating that these oocytes are more sensitive to radiationinduced change than are the larger cells. The number of large cells was significantly increased after exposure to up to $10,000 \mathrm{r}$, supporting the conclusion from Exps. I and II that contracted cells are transformed into large ones. A reduction in the number of large germ cells only became apparent when the total population of primordial oocytes had fallen to about $15 \%$ of control values, and when very few contracted cells were recorded. This stage was reached 16 days after exposure to $15,000 \mathrm{r}$ and 32 days after $5000 \mathrm{r}$ (see Table 3 ). The minimum dose required to eliminate all but a few oocytes within 32 days was as high as $15,000 \mathrm{r}$, supporting the conclusion that oocytes of the guinea-pig are highly radioresistant 
TABLE 3

NUMBERS OF GERM CELLS FOUND IN OVARIES OF GUINEA-PIGS KILLED (A) 16 OR (B) 32 DAYS AFTER X-IRRADIATION WITH 500 TO 15,000 R

\begin{tabular}{|c|c|c|c|c|c|c|c|}
\hline \multirow{3}{*}{$\begin{array}{c}\begin{array}{c}\text { No. of } \\
\text { animals }\end{array} \\
\text { A } 5\end{array}$} & \multirow{3}{*}{$\begin{array}{c}\begin{array}{c}\text { Dose } \\
(r)\end{array} \\
500\end{array}$} & \multirow[b]{3}{*}{$\begin{array}{l}\text { Irrad. } \\
\text { Control }\end{array}$} & \multicolumn{4}{|c|}{ Mean numbers and percentages of germ cells } & \multirow{3}{*}{$\begin{array}{c}\begin{array}{c}\text { Irrad./Contro } \\
(\%)\end{array} \\
79\end{array}$} \\
\hline & & & \multicolumn{2}{|c|}{ Large } & Contracted & Total & \\
\hline & & & $\begin{array}{l}2346 \\
1404\end{array}$ & $29 \%$ & $\begin{array}{l}5766 \\
8068\end{array}$ & $\begin{array}{l}8112 \\
9472\end{array}$ & \\
\hline 4 & 1000 & $\begin{array}{l}\text { Irrad. } \\
\text { Control }\end{array}$ & $\begin{array}{l}8083 \\
3560\end{array}$ & $\begin{array}{l}95 \% \\
41 \%\end{array}$ & $\begin{array}{r}520 \\
6518\end{array}$ & $\begin{array}{r}8603 \\
10078\end{array}$ & 84 \\
\hline 5 & 5000 & $\begin{array}{l}\text { Irrad. } \\
\text { Control }\end{array}$ & $\begin{array}{l}6794 \\
4382\end{array}$ & $100 \%$ & $\begin{array}{r}18 \\
5834\end{array}$ & $\begin{array}{r}6812 \\
10216\end{array}$ & 70 \\
\hline 5 & 10000 & $\begin{array}{l}\text { Irrad. } \\
\text { Control }\end{array}$ & $\begin{array}{l}3512 \\
3466\end{array}$ & $\begin{array}{l}88 \% \\
40 \%\end{array}$ & $\begin{array}{r}810 \\
5786\end{array}$ & $\begin{array}{l}4322 \\
9252\end{array}$ & 43 \\
\hline 5 & 15000 & $\begin{array}{l}\text { Irrad. } \\
\text { Control }\end{array}$ & $\begin{array}{l}1460 \\
5038\end{array}$ & $100 \%$ & $\begin{array}{r}6 \\
6464\end{array}$ & $\begin{array}{r}1464 \\
11502\end{array}$ & 14 \\
\hline B 5 & 500 & $\begin{array}{l}\text { Irrad. } \\
\text { Control }\end{array}$ & $\begin{array}{l}3112 \\
1330\end{array}$ & $33 \%$ & $\begin{array}{r}5928 \\
14336\end{array}$ & $\begin{array}{r}9040 \\
15666\end{array}$ & 61 \\
\hline 5 & 1000 & $\begin{array}{l}\text { Irrad. } \\
\text { Control }\end{array}$ & $\begin{array}{l}3158 \\
2226\end{array}$ & $\begin{array}{l}71 \% \\
19 \%\end{array}$ & $\begin{array}{l}1140 \\
8780\end{array}$ & $\begin{array}{r}4298 \\
11006\end{array}$ & 44 \\
\hline 5 & 5000 & $\begin{array}{l}\text { Irrad. } \\
\text { Control }\end{array}$ & $\begin{array}{l}1206 \\
2146\end{array}$ & $\begin{array}{l}99 \% \\
30 \%\end{array}$ & $\begin{array}{r}16 \\
7110\end{array}$ & $\begin{array}{l}1222 \\
9256\end{array}$ & 11 \\
\hline 5 & 10000 & $\begin{array}{l}\text { Irrad. } \\
\text { Control }\end{array}$ & $\begin{array}{r}552 \\
4212\end{array}$ & $\begin{array}{l}100 \% \\
50 \%\end{array}$ & $\begin{array}{r}0 \\
5546\end{array}$ & $\begin{array}{r}552 \\
9785\end{array}$ & 8 \\
\hline 5 & 15000 & $\begin{array}{l}\text { Irrad. } \\
\text { Control }\end{array}$ & $\begin{array}{r}174 \\
2806\end{array}$ & $\begin{array}{l}100 \% \\
42 \%\end{array}$ & $\begin{array}{r}0 \\
5274\end{array}$ & $\begin{array}{r}174 \\
8080\end{array}$ & 2 \\
\hline
\end{tabular}

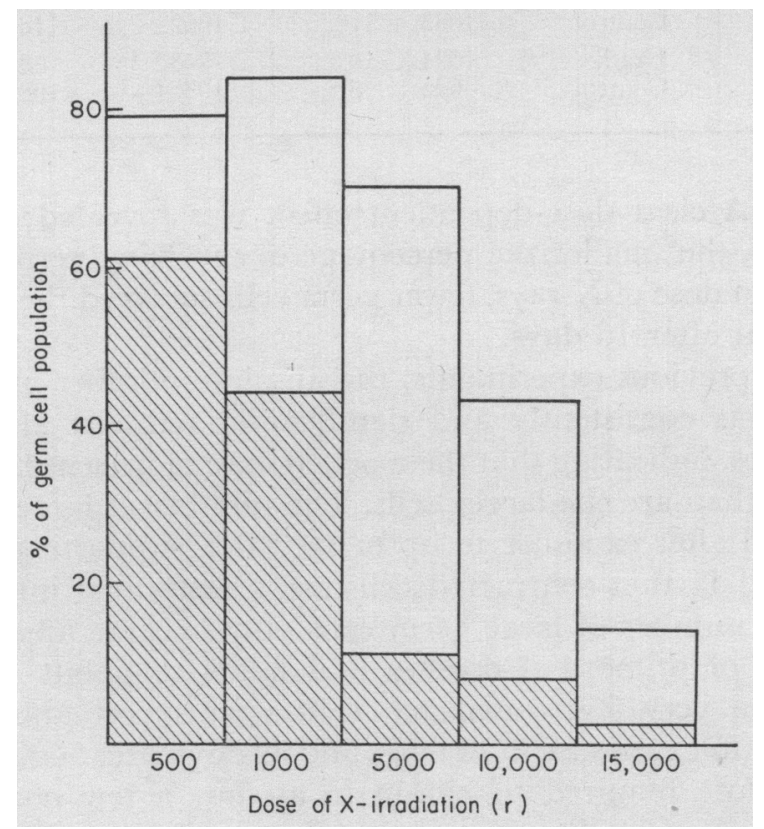

TExT-Fig. 1. Mean percentage of germ cell population surviving 500 to $15,000 \mathrm{r}$ for 16 days (open columns) or 32 days (shaded columns). 
The considerable difference between the dose which destroys about half the population within 32 days $(500$ to $1000 \mathrm{r}$ ) and that required to sterilize the ovary $(15,000 \mathrm{r})$ suggests that oocytes in primordial follicles in the guinea-pig might be heterogeneous with regard to radiosensitivity. It seems possible that primordial oocytes with contracted nuclei constitute a reservoir population; that these cells are more prone to radiation damage than are those with large nuclei, but that damage only becomes manifest after transformation to the large condition.

\section{DISCUSSION}

In the first two experiments, in which female guinea-pigs were exposed to 300 to $10,000 \mathrm{r}$ and killed after 3 days, there was a highly significant fall in the numbers of contracted oocytes. In marked contrast, there was no significant change in the total population of germ cells. It seemed that 3 days might be insufficient for damaged cells to be eliminated, and so a third, more extensive experiment was performed, to record changes 16 and 32 days after exposure to 500 to $15,000 \mathrm{r}$. The results revealed a clear dose effect: the higher the dose of $\mathrm{X}$-rays (or, with a given dose, the longer the post-irradiation interval), the smaller the percentage of surviving germ cells. These findings lead to several conclusions: firstly, contracted oocytes in primordial follicles are more sensitive to radiation-induced changes than are large oocytes; secondly, X-irradiation stimulates contracted germ cells to take up the large nuclear configuration; and thirdly, transformation to the large condition probably precedes degeneration and ultimate elimination from the ovary.

So far as I am aware, no previous attempt has been made to assess the effects of X-irradiation on contracted as opposed to large oocytes in primordial follicles. There appears to be a consensus that larger follicles are more sensitive to radiation than are small follicles (Eymer, 1918; Fritschi, 1927; Genther, 1931; Oakberg \& Clark, 1962, 1964), but the experimental results presented here do not throw any further light on this question.

Contracted oocytes also occur in a number of other species, although their numbers have not been reported to fluctuate through development as they do in the guinea-pig. They may be seen in adult ovaries from the rabbit and the ferret (Ioannou, unpublished observations), and Erickson (1965, 1966a, b, 1967) has described them in cattle, where he believes they represent a pachytene stage of development. Baker \& Franchi (1967a), however, have refuted this suggestion by observations on the ultrastructure of oocyte chromosomes in both pre- and post-natal cattle. They found synaptinemal complexes (typical of the pachytene stage) in oocytes of pre-natal specimens, but only diplotene oocytes in post-natal animals.

Erickson $(1965,1967)$ also claimed that contracted oocytes (which he found only in primordial follicles) are considerably more radioresistant than the diplotene or dictyate stages found in growing and Graafian follicles respectively. If this were correct, it would appear to contrast markedly with the condition in the guinea-pig, where the contracted cells are the more sensitive.

It was suggested by Mandl (1964) that radiosensitivity may be related to the 
chromosomal configuration of the cell at the time of exposure. Baker \& Franchi (1967b) have gone further, and suggested that differences in radiosensitivity of oocytes between (a) species and (b) different stages of follicular development, are due to differences in the degree of diffusion of the chromosomal material in the form of lateral projections of the lampbrush type. Miller, Carrier \& von Borstel (1965) found that lampbrush chromosomes in the newt were highly resistant to radiation damage, and they suggested that the ribonucleoprotein associated with the lateral loops of the chromosomes might have a 'splinting' action in holding the ends of the chromosomes together. Chromosomes of the large oocyte in the guinea-pig are more diffuse than those of the contracted cell (Ioannou, 1964) and appear to bear lateral projections. On the hypothesis advanced by Miller et al. (see also Sobels, 1963), such cells should be more radioresistant than the contracted cells, the chromosomes of which lack lateral projections; and experimental results support this expectation. The results of a preliminary experiment (to be published later) to compare the rate of RNA synthesis in contracted and large oocytes suggest that the turnover of RNA is greater in large cells. If this were so, it would help to explain their relatively greater radiosensitivity in terms of the suggestion that resistance is somehow associated with protein synthesis. It would also help to explain the enormous difference in sensitivity between primordial oocytes of the guinea-pig $\left(\mathrm{LD}_{50 / 32}\right.$ about $1000 \mathrm{r}$ ) and those of the rat and mouse $\left(\operatorname{LD}_{50 / 30}\right.$ less than $\left.100 \mathrm{r}\right)$. All three are rodent species, but the rat and the mouse both have primordial oocytes with dictyate nuclei, morphologically very different from the nuclear configuration shown by oocytes of the guinea-pig.

\section{ACKNOWLEDGMENTS}

The expenses incurred in this study were defrayed from grants made to Professor Sir Solly Zuckerman by the Population Council and by the Medical Research Council; and to Dr H. M. Beaumont by the U.S. Atomic Energy Commission. The X-ray apparatus was generously provided by the Nuffield Foundation.

The author wishes to express his thanks to Dr J. Herbert and Professor P. L.

Krohn for their valuable criticism in the preparation of this manuscript, and to Dr H. M. Beaumont for her constant advice and encouragement.

\section{REFERENCES}

Baker, T. G. (1963) A quantitative and cytological study of germ cells in human ovaries. Proc. R. Soc. B, $158,417$.

BAKER, T. G. (1966) The sensitivity of oocytes in post-natal rhesus monkeys to X-irradiation. F. Reprod. Fert. 12, 183.

BAKER, T. G. \& FRANGHI, L. L. (1967a) The structure of the chromosomes in human primordial oocytes. Chromosoma, 22, 358.

BAKER, T. G. \& FRANCHI, L. L. (1967b) The fine structure of oogonia and oocytes in human ovaries. 7. Cell Sci. 2, 212.

Beaumont, H. M. (1961) The radiosensitivity of oogonia and oocytes in the foetal rat. Int. F. Radiat. Biol. 3, 59.

Beaumont, H. M. (1962) The radiosensitivity of germ cells at various stages of ovarian development. Int. F. Radiat. Biol. 4, 581.

ERICKsON, B. H. (1965) Symposium on atomic energy in animal science: radiation effects on gonadal development in farm animals. F. Anim. Sci. 24, 568. 
ERICKson, B. H. (1966a) Development and senescence of the postnatal bovine ovary. F. Anim. Sci. 25, 800.

ERIGKson, B. H. (1966b) Development and radio-response of the prenatal bovine ovary. J. Reprod. Fert. 11, 97.

ERICkson, B. H. (1967) Effect of gamma radiation on the prepuberal bovine ovary. Radiat. Res. 31, 441.

Eymer, H. (1918) Experimentelles zur Bleifilterstrahlung. Strahlentherapie, 8, 387.

FRITSCHI, G. (1927) Quantitativ-histologische Untersuchungen am normalen Ovar und am Röntgenovar des Meerschweinchens. Acta radiol. 8, 209.

Genther, I. T. (1931) Irradiation of the ovaries of guinea-pigs and its effects on the oestrous cycle. Am. F. Anat. 48, 99.

Green, S. H. \& Zuckerman, S. (195I) The number of oocytes in the mature rhesus monkey (Macaca mulatta). F. Endocr. 7, 194.

Green, S. H. \& Zuckerman, S. (1954) Further observations on oocyte numbers in mature rhesus monkeys (Macaca mulatta). F. Endocr. 10, 284.

Ioannou, J. M. (1964) Oogenesis in the guinea-pig. 7. Embryol. exp. Morph. 12, 673.

Mande, A. M. (1959) A quantitative study of the sensitivity of oocytes to X-irradiation. Proc. R. Soc. B, $150,53$.

Mande, A. M. (1964) The radiosensitivity of germ cells. Biol. Rev. 39, 288.

MANDL, A. M. \& Zuckerman, S. (1951) Numbers of normal and atretic oocytes in unilaterally spayed rats. F. Endocr. 7, 112.

Miller, O. L., Carrier, R. F. \& von Borstel, R. G. (1965) In situ and in vitro breakage of lampbrush chromosomes by X-irradiation. Nature, Lond. 206, 905.

OAKBeRg, E. F. \& Clark, E. (1961) Effect of dose and dose rate on radiation damage to mouse spermatogonia and oocytes as measured by cell survival. F. cell. comp. Physiol. 58, Suppl. 1, 173.

OAKBERG, E. F. \& ClaRK, E. (1962) Species differences in radiation response of the mammalian primary oocyte. (Abstract). Genetics, Princeton, 47, 974.

OAKBERG, E. F. \& CLARK, E. (1964) Species comparison of radiation response of the gonads. In: Effects of Ionizing Radiation on the Reproductive System. Eds. W. D. Carlson and F. X. Gassner. Pergamon Press, Oxford.

Peters, H. (1961) Radiation sensitivity of oocytes at different stages of development in the immature mouse. Radiat. Res. 15, 582.

Sosels, F. H. (1963) Repair and differential radiosensitivity in developing germ cells of Drosophila males. In: Repair from Genetic Radiation Damage and Differential Radiosensitivity in Germ Cells. Ed. F. H. Sobels. Pergamon Press, London.

VAN Eck-Vermande, G. J. (1956) Neo-oogenesis in adult monkey: consequences of atresia of oocytes. Anat. Rec. 125, 207. 